\title{
TISSUE EXPANDER COMPLICATIONS IN PLASTIC SURGERY. A 10-YEAR EXPERIENCE
}

\author{
Marcelo Sacramento Cunha, Hugo Alberto Nakamoto, Marisa Roma Herson, \\ José Carlos Faes, Rolf Gemperli and Marcus Castro Ferreira
}

RHCFAP/3076

CUNHA MS et al. - Tissue expander complications in plastic surgery. A 10-year experience. Rev. Hosp. Clín. Fac. Med. S. Paulo 57(3): 2002.

INTRODUCTION: Tissue expanders have been of great value in plastic surgery. Tissue expansion was developed for a specific indication; however, within a very short time, the concept of tissue expansion found wide applicability. From 1990 to 1999,315 expanders in 164 patients were utilized. A retrospective analysis of complications and prognostic factors for complications were done.

METHODS: The indications for tissue expansion were burns (50\%), trauma (32\%), and sequelae of previous surgery $(8.8 \%)$. The expanders were inserted most frequently in the scalp, trunk and neck.

RESULTS: There were $22.2 \%$ of complications and the most common were expander exposure (50\%), infection (24\%) and bad function of the expander $(12.8 \%)$. The present study revealed an increased rate of minor complications in the group of 0 to 10 years of age and an increased rate of major complications for face and neck expansions compared to trunk expansion. There were no increased complication rates for the other age and anatomic site groups, previous expansion, concomitant expansion and type of expander used.

CONCLUSIONS: The outcomes from tissue expansion procedures done in our hospital are similar to those reported in the literature. Tissue expansion is a good and safe technique.

DESCRIPTORS: Tissue expansion. Tissue expander. Expansion complication. Expanded flap.

Tissue expansion has developed as a routine procedure in plastic surgery in the past two decades. In 1956, Neumann was the first to recognize the potential of tissue expansion for reconstructive surgery. He implanted a balloon beneath the temporal region for reconstruction of an absent ear. In 1976, Radovan used the tissue expander concept for reconstruction of the breast after mastectomy. Subsequently, the use of tissue expansion has been popularized among plastic surgeons and has become the treatment method of choice for many congenital and acquired defects in children and adults ${ }^{1-3}$.

Expanders are silicone envelopes that have self-sealing injection ports (Fig. 1). At weekly intervals, saline is progressively injected through the port and passes into the expander, which enlarges. As the volume inside the implant increases, tension placed on the overlying and adjacent tissues increases ${ }^{4}$. The expanded skin undergoes histological changes that are well documented: the epidermis exhibits increased mitotic activity, there is recruitment of adjacent tissue, which is believed to contribute to the additional skin, the dermis thins considerably but it is often masked clinically by the thick fibrous capsule that forms around the implant ${ }^{5}$. Skin expansion

From the Division of Plastic Surgery, Hospital das Clínicas, Faculty of Medicine, University of São Paulo. allows the surgeon to generate additional amounts of precious tissue, to thin the flap, and to increase its vascularity ${ }^{6}$.

Tissue expansion was developed for specific indications. It allows surgeons to cover defects using local skin of appropriate color, texture, and adnexal structure ${ }^{7}$. Aesthetic subunits of the face can be replaced by skin of identical or similar qualities, and distant donor sites can be avoided. Sensate and hair-bearing skin can be expanded and used for specialized areas of facial reconstruction; usually, the color and texture match are excellent ${ }^{8}$.

Despite the great benefit conferred by tissue expansion, it has resulted in some morbidity. Complication rates of 
20 to 40 percent when performing tissue expansion in children have been reported ${ }^{8}$. Patients with high risk of complication should be identified.

The method was introduced in the Division of Plastic Surgery of the Hospital das Clinicas in the early 1980s, and the initial indications, anatomic sites,

Table 1 - Indications for tissue expansion.

\begin{tabular}{lc}
\hline Indications & Percent $(\%)$ \\
\hline Burns & $157(50 \%)$ \\
Trauma & $101(32 \%)$ \\
Previous surgery & $28(9 \%)$ \\
Others & $29(9 \%)$ \\
\hline
\end{tabular}

Table 2 - Age and complications.

\begin{tabular}{lccc}
\hline Age & Number $(\%)$ & Major complications $(\%)$ & Minor complications $(\%)$ \\
\hline 0 to 10 years & $67(21.3 \%)$ & $10(14.9 \%)$ & $*+4(5.9 \%)$ \\
11 to 20 years & $112(35.6 \%)$ & $20(17.8 \%)$ & $* 1(0.9 \%)$ \\
21 to 40 years & $111(35.2 \%)$ & $25(22.5 \%)$ & $4(3.6 \%)$ \\
$>40$ years & $25(7.9 \%)$ & $6(24 \%)$ & +0 \\
\hline
\end{tabular}

*: $P<0.05$

Table 3 - Anatomic site and complications.

\begin{tabular}{lccc}
\hline Anatomic site & Number $(\%)$ & Major complications (\%) & Minor complications (\%) \\
\hline Scalp & $72(22.8 \%)$ & $15(20.8 \%)$ & $3(4.1 \%)$ \\
Trunk & $72(22.8 \%)$ & $* 9(12.5 \%)$ & $3(4.1 \%)$ \\
Upper Extremity & $35(11.1 \%)$ & $5(14.3 \%)$ & $2(5.7 \%)$ \\
Lower Extremity & $42(13.3 \%)$ & $8(19 \%)$ & $1(2.4 \%)$ \\
Face and Neck & $94(29.9 \%)$ & $* 24(25.5 \%)$ & 0 \\
\hline
\end{tabular}

$*: P<0.05$

Table 4 - Type of expander and complications.

\begin{tabular}{lccc}
\hline Expander type & Number $(\%)$ & Major complications (\%) & Minor complications (\%) \\
\hline Croissant & $145(46 \%)$ & $30(20.7 \%)$ & $3(2 \%)$ \\
Retangular & $139(44.1 \%)$ & $25(17.9 \%)$ & $5(3.6 \%)$ \\
Round & $31(9.8 \%)$ & $6(19.3 \%)$ & $1(3.2 \%)$ \\
\hline
\end{tabular}

technique, results, and complications were reviewed in the early 1990 s by Gemperli et al. ${ }^{9-11}$. It seems appropriate now to review the complications and the prognostic factors for complications of cutaneous expansion, compared with the former experience. A retrospective review of the experience of the last decade was undertaken, and its presentation is the purpose of this paper.

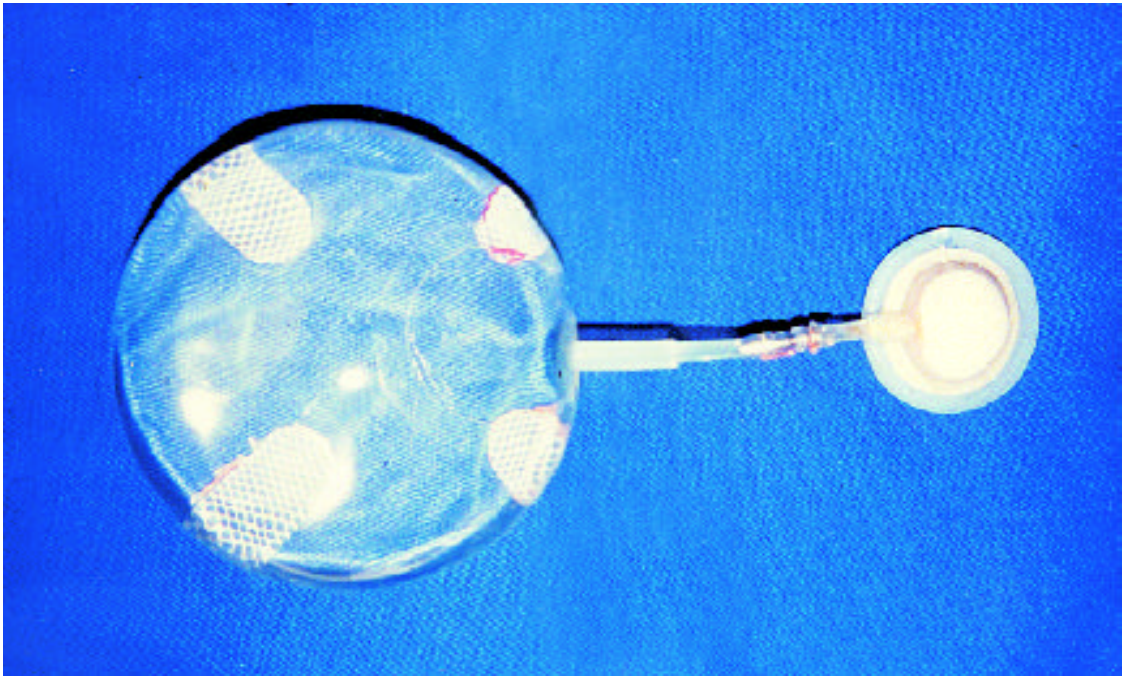

Figure 1 - Tissue expander.

were males. The most common indication for tissue expansion was burn sequelae, trauma, and scars from previous surgery (Table 1).

The ages of patients ranged from 3 to 52 years (average 20.9 years). There were 67 expanders placed in patients of 0 to 10 years $(21.3 \%), 112$ in patients of 11 to 20 years $(35.6 \%), 111$ in patients of 21 to 40 years $(35.2 \%)$, and 25 in patients of 40 years or more $(7.9 \%$ ) (Table 2 ). The anatomic sites of expansion included the scalp (72 expansions), trunk (72), face and neck (94), lower extremities (42), and upper extremities (35) (Table 3). "Croissant" expanders were used in 145 cases, rectangular expanders in 139, and round expanders in 31 (Table 4). Expanders were placed in a site of one prior expansion in 78 cases (24.8\%) (Table 5). Concomitant expansion was done in 145 expansions (46\%) (Table 6).

The medical records and operative reports of all patients were analyzed. Each patient was studied with respect to indication for the procedure, location, and shape of expander, previous expansion if any, concomitant expansion, and complications. Data such as expander volume and dimensions were not always found in the medical records and could not be used in this study.

The results were evaluated using the rate of complications as criteria of fulfillness of the reconstruction. Those 
Table 5 - Previous expansion and complications.

\begin{tabular}{|c|c|c|c|}
\hline Previous expansion & Number $(\%)$ & Major complications (\%) & Minor complications (\%) \\
\hline $\begin{array}{l}\text { With previous } \\
\text { expansion }\end{array}$ & $78(24.8 \%)$ & $12(15.4 \%)$ & $1(1.3 \%)$ \\
\hline $\begin{array}{l}\text { Without previous } \\
\text { expansion }\end{array}$ & $237(75.2 \%)$ & $49(20.6 \%)$ & $8(3.3 \%)$ \\
\hline
\end{tabular}

Table 6 - Concomitant expansion and complications.

\begin{tabular}{lccc}
\hline $\begin{array}{l}\text { Concomitant } \\
\text { expansion }\end{array}$ & Number (\%) & Major complications (\%) & Minor complications (\%) \\
$\begin{array}{l}\text { With concomitant } \\
\text { expansion }\end{array}$ & $145(46 \%)$ & $29(20 \%)$ & $3(2 \%)$ \\
$\begin{array}{l}\text { Without concomitant } \\
\text { expansion }\end{array}$ & $170(54 \%)$ & $32(18.8 \%)$ & $6(3.5 \%)$ \\
\hline
\end{tabular}

cases with no complications were classified as a satisfactory result. Complications were divided into major and minor categories. Major complication was defined as that resulting in a premature loss of expander that required additional surgery, or when the preoperative plan was not completed, thus yielding a poor result. The minor complication was defined as that resulting in only partial satisfaction of the preoperative plan and thus defined as a fair result ${ }^{12}$.

The data were analyzed to determine the possible correlation of the complications and those factors studied. The Student $t$ test was used to test for statistic significance, and $P<0.05$ was considered statistically significant.

\section{RESULTS}

Complications were identified in 70 placed expanders $(22.2 \%)$. These included 36 exposures of the implant $(51.4 \%$ of complications), 17 cases of infections (24.4\%), 15 expander failures $(21.4 \%)$ of which 9 were port failures (12.9\%), 4 expander ruptures $(5.7 \%), 2$ expander perforations $(2.8 \%), 1$ hematoma $(1.4 \%)$, and 1 suture dehiscence $(1.4 \%)$. There were major complications in 61 cases $(87 \%$ of the complications) and minor complications in 9 expansions ( $13 \%$ of the complications).

Patients of 0 to 10 years of age had more minor complications than patients of 11 to 20 years or patients of more than 40 years of age. Occurrences of minor complications were not significantly different at any anatomic site (Table 2).

Patients with expanders on the face and neck experienced more major complications $(25.5 \%)$ than those with expanders on the trunk (12.5\%) (Table 3). The relationship between the minor complications and anatomic sites of expansion was not statistically significant.

There was no statistic significance between expander type and major or minor complications (Table 4). In the group with previous expansion, there were $15.4 \%$ major complications and $1.3 \%$ minor complications; whereas, when expansions were placed in a site with no previous expansion, there were $20.6 \%$ major complications and $3.3 \%$ minor complications. Differences between the two groups were not statistically significant (Table 5).

In the group with concomitant expansion, 20\% major complications and $2 \%$ minor complications occurred; whereas, in the group with no concomitant expansion $18.8 \%$ major complications and $3.5 \%$ minor complications occurred. Differences between the two groups were not statistically significant (Table 6 ).

\section{DISCUSSION}

Cutaneous expansion is used increasingly in reconstructive surgery for the treatment of a variety of problems in children and adults. The reconstruction of many congenital and acquired defects has been made possible through the use of this technique ${ }^{3}$.

Advantages of tissue expansion include no new unduly disfiguring defects, the avoidance of distant flaps, sensation maintenance, good color and texture match, preservation of hair-bearing quality, and increased vascularity and greater length of survival of random flaps elevated in expanded skin. Disadvantages of tissue expansion are frequent office visits for inflation, discomfort, and a period of increased deformity during the time of inflation. In the pediatric population, emotional disturbances may accompany the use of tissue expanders. Formation of a scar tissue capsule may result in reduced skin elasticity, and impeded flap movement and expanded skin has a tendency for postoperative retraction ${ }^{13}$.

The tissue expander was first used in our medical center in 1984. The experience of the Division during the period of 1984 to 1990 was studied by Gemperli at al. in 19919-11. Twenty-five patients used tissue expanders in the upper limbs, and $12 \%$ major complications were reported by Gemperli in $1991^{10}$. The present study reported similar rates of complications: $14.3 \%$ major complications and $57 \%$ minor complications in 35 patients with upper limbs expansions. In the period spanning 1984 to 1990,33 patients with tissue expanders placed in lower limbs were studied, and $51.9 \%$ major complications and $25 \%$ minor complications were reported; whereas, in the present study, $19 \%$ major complications and $2.4 \%$ minor complications in 42 patients occurred ${ }^{9}$. The lower complication rates could have resulted from more experience with the technique and better selection of patients. Cases of higher complexity were treated with other techniques such as free flaps, since the previous study and the literature showed a higher complication rate for tissue expansion. Tissue expanders were used in the scalp in 32 patients during the period of 1984 to 1990 , and 5 (15.6\%) minor complications were reported; the present 
study reported higher rates: $20.8 \%$ major complications and $4.1 \%$ minor complications in 72 patients ${ }^{11}$. The number of patients studied was more than 2 times that of the previous study, and this fact could represent more indications for the technique. Cases of higher complexity were treated, since tissue expanders were considered in the literature to be the best option for scalp reconstruction. Including cases of higher complexity may have resulted in higher complication rates than in the initial study.

Tissue expanders have been the

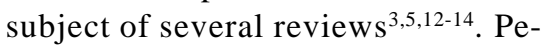
diatric and burned populations have been the most studied patients. A substantial incidence of complications has been well documented. The overall complication rates reported in the literature are $13 \%$ to $40 \%$. Expander complication rates in pediatric burn patients range from $9 \%$ to $37 \%{ }^{12}$.

The present study analyzed a young population (average 20.9 years) with a predominance of female patients $(61.5 \%)$. The most common indication for tissue expansion was burn sequelae, trauma, and scars from previous surgery. These epidemiological factors are similar to those in other series.

The overall, minor, and major complication rates in this study were $22.2 \%$, $2.8 \%$, and $19.4 \%$, respectively, which are similar to those in other reported series. Complications reported in the literature include primarily infection, exposure of the implant, and implant failure. Other complications are port failure, pain, hematoma, seroma, bone resorption, dog ears, and wide scars ${ }^{13}$. Complications reported in this study included 36 exposures of implant (51.4\% of the complications), 17 infections (24.4\%), 9 port failures $(12.9 \%), 4$ expander ruptures $(5.7 \%), 2$ expander perforations $(2.8 \%), 1$ hematoma $(1.4 \%)$, and 1 suture dehiscence (1.4\%).

In 1996, Friedman reported a 6-year experience with tissue expanders in children. The overall complication rate was $18 \%$. The factors associated with a statistically significant increase in complications were burns and soft-tissue loss, patient age under 7 years, use of internal expander ports, and a history of 2 or more prior expansions ${ }^{8}$. The adult literature reveals a high complication rate with expansion in lower extremities resulting from limitations of vascularity and available tissue. Bauer asserts that both upper and lower extremity expansion have a high complication rate ${ }^{6}$. In 1998, Pisarski observed an increased complication rate for lower extremity expansion and poor surgeon experience $^{12}$. Gibstein in 1997 reviewed 105 children in whom 191 tissue expanders were placed. The complications were related to age, being higher in children (aged 1 to 12 years) 5 .

An increased rate of minor complications was found in the present study in the group of 0 to 10 years of age, and an increased rate of major complications for face and neck expansions compared to trunk expansion. There was no increased complication rate for the other age and anatomic site groups, previous expansion, concomitant expansion, and type of expander used. The wide variety of surgeons in the service prevented the analysis of the contribution of surgeon experience to the complication rate.

Tissue expansion is a useful method of achieving reconstruction of any site of body where there is little available tissue. The best results depend on careful patient selection, meticulous attention to detail, and involvement of a multidisciplinary team. 
CUNHA MS e col. - Complicações de expansores teciduais em cirurgia plástica. Dez anos de experiência. Rev. Hosp. Clín. Fac. Med. S. Paulo 57(3): 2002.

INTRODUÇÃO: A utilização de expansores teciduais tem sido de grande importância para a Cirurgia Plástica. Inicialmente descritos para correção de uma deformidade específica, logo tiveram sua utilização ampliada para deformidades congênitas e adquiridas. Foram utilizados 315 expansores em 164 pacientes no período de Janeiro de 1990 a Dezembro de 1999. Uma análise retrospectiva das complicações e fatores prognósticos para complicações foi realizada.

MÉTODO: As deformidades tratadas mais freqüentes foram seqüelas de queimaduras $(50 \%)$, sequielas de traumas $(32 \%)$ e sequielas de cirurgias prévias $(8,8 \%)$. Os sítios anatômicos em que mais freqüentemente foram utilizados compreenderam face e pescoço, couro cabeludo e tronco.

RESULTADOS: As complicações ocorreram em $22,2 \%$ das expansões e as mais comuns foram extrusão (50\%), infecção $(24 \%)$ e mau funcionamento do expansor (12,8\%). No grupo etário de 0 a 10 anos predominaram com plicações menores e no grupo que utilizou expansor na face e pescoço as complicações foram maiores comparativamente ao grupo que utilizou expansores no tronco. Não houve relação causa-efeito entre complicações e expansões prévias, uso concomitante de expansores e tipo do expansor.

CONCLUSÃO: Os resultados são semelhantes aos da Literatura. A utilização do expansor tecidual é técnica segura e com bons resultados.

DESCRITORES: Expansores teciduais. Expansão tecidual. Complicação expansor. Retalho expandido.

\section{REFERENCES}

1.BAUER BS, JOHNSON PE \& LOVATO G - Applications of soft tissue expansion in children. Clin Plast Surg, 1987; 14:549.

2.RADOVAN C - Tissue expansion soft-tissue reconstruction. Plast Reconstr Surg, 1984; 74:482.

3.ICONOMOU TG, MICHELOW BJ \& ZUKER RM - Tissue expansion in the pediatric patient. Ann Plast Surg, 1993; 31:134.

4.ARGENTA LC - Tissue expansion. In: AST ON SJ, BEASLEY RW $\&$ THORNE CHM - Plastic Surgery. $5^{\text {th }}$ ed. New York, Lippincott-Raven, 1997. p.91.

5.GIBSTEIN LA, ABRAMSON DL \& BARTLETT RA - Tissue expansion in children: a retrospective study of complications. Ann Plast Surg, 1997; 38:358

6.BAUER BS, VICARI FA \& RICHARD ME - The role of tissue expansion in pediatric plastic surgery. Clin Plast Surg, 1990; 17:101.

7.ARGENTA LC, MARKS MW \& PASYK KA - Advances in tissue expansion. Clin Plast Surg, 1985; 12:159.

8.FRIEDMAN RM, INGRAM AE \& ROHRICH R J - Risk factors for complications in pediatric tissue expansion. Plast Reconstr Surg, 1996; 98:1242.
9.GEMPERLI R - Emprego dos expansores de tecidos na reparação cutânea do membro inferior. São Paulo, 1991. (Tese - Faculdade de Medicina da Universidade de São Paulo).

10.GEMPERLI R, FERREIRA MC, TUMA JR P et al. - The use of tissue expanders in the upper limbs. Rev Soc Bras Cir Plast, 1990; 5:75-80.

11.GEMPERLI R, FERREIRA MC, MANDERS EK et al. - O uso de expansores de tecidos no couro cabeludo. Rev Hosp Clin Fac Med S Paulo, 1991; 46:112-115.

12.PISARSKI GP, MERTENS D \& WARDEN GD - Tissue expander complications in the pediatric burn patient. Plast Reconstr Surg, 1998; 102:1008.

13.CHUN JT \& ROHRICH RJ - Versatility of tissue expansion in head and neck burn reconstruction. Ann Plast Surg, 1998; 41:11-16.

14.STILL J, CRAFT-COFFMAN B \& LAW E - Use of pedicle flaps and tissue expanders to reconstruction burns scars of the anterior abdomen and chest wall. Ann Plast Surg, 1998; 40:226.

Received for publication on June 06, 2001. 